
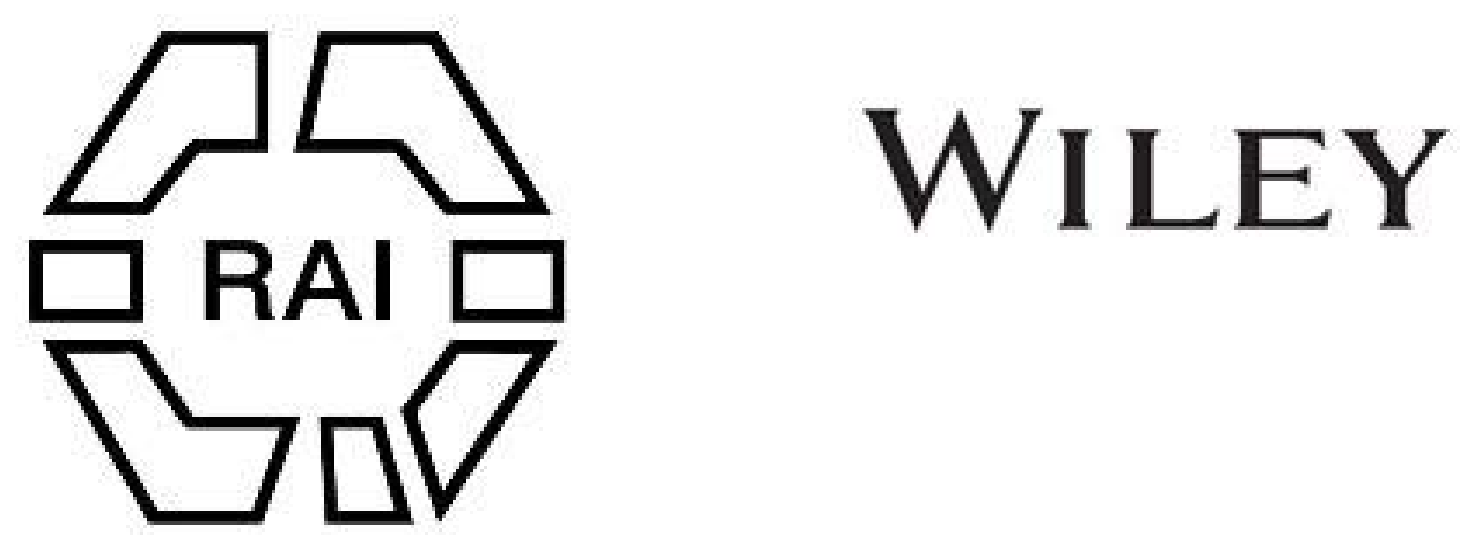

46. Sex and Growth Features in Racial Analysis: An Abstract of a Communication Read Before the Royal Anthropological Institute of February 28th, 1922

Author(s): R. M. Fleming

Source: Man, Vol. 22 (May, 1922), pp. 69-75

Published by: Royal Anthropological Institute of Great Britain and Ireland Stable URL: http://www.jstor.org/stable/2840042

Accessed: 27-06-2016 04:51 UTC

Your use of the JSTOR archive indicates your acceptance of the Terms \& Conditions of Use, available at

http://about.jstor.org/terms

JSTOR is a not-for-profit service that helps scholars, researchers, and students discover, use, and build upon a wide range of content in a trusted digital archive. We use information technology and tools to increase productivity and facilitate new forms of scholarship. For more information about JSTOR, please contact support@jstor.org.

Royal Anthropological Institute of Great Britain and Ireland, Wiley are collaborating with JSTOR to digitize, preserve and extend access to Man 
“ entre les deux pouces, lorsqu'il encercle entre ses mains fermées l'extrémité du " conduit de paille. Dans cette pipe d'argile, les Sikhs fument, à défaut de " ' hookah,' du tabac, et, à défaut de tabac, n'importé quelle herbe sèche." Fig. 11 is copied from the illustration by $\mathbf{R}$. Caton Woodville which accompanies the description. This improvised pipe appears to be a portable derivative from the built-up earth-pipe, and, except for the addition of a straw "stem," is almost identical with the South African pottery pipe shown in Fig. 3.

The parallelism between these various smoking methods in South Africa and Central Asia may be carried still further if we compare in the two regions a very simple type of clay or mud pipe which has also, probably, an origin traceable to the built-up earth-pipes. Fig. 5 represents a very rudimentary pipe such as is made by Kaffir convicts in Natal for illicit smoking. It is merely a tapering tube of baked clay, about 4 inches long, open at both ends. The wider end serves as "bowl," the narrower as mouthpiece. There is no demarkation between "bowl" and mouthpiece, the bore tapering gradually from one end to the other. This pipe was obtained by Dr. H. D. Kingston. Fig. 6 shows an almost identical form of pipe obtained by Mr. W. Crooke at Nasirabad in Rajputana; made of sun-dried mud (or, possibly, camel dung) very full of grass fragments. Its form differs from that of the Kaffir example only in size and in the "bowl" being demarkated from the stem by a sudden narrowing of the bore about half way down the pipe.

These hurried notes do not pretend to exhaust the subject, but aim merely at emphasising how very closely the varieties of earth-pipes and their derivatives correspond in the two regions dealt with. The resemblances are sufficiently striking and numerous to suggest that they must be explained by the assumption of a culturelink between the two widely-separated areas.

The actual specimens figured (Figs. 1 to 6 ) are now all in the Pitt Rivers Museum at Oxford, and are reproduced on the scale of one half linear measurement.

HENRY BALFOUR.

\section{Physical Anthropology.}

Fleming.

Sex and Growth Features in Racial Analysis : an abstract of a communication read before the Royal Anthropological 46 Institute on February 28th, 1922. By Miss R. M. Fleming.

A few years ago, as a student in the department of geography and anthropology at Aberystwyth University, I began a study of women and children which I hoped would be a supplement to Professor Fleure's survey of the adult male Welsh population, and would show how far sex and growth, as well as race type, influence physical characters. A good foundation of data to work upon is now available, as I have measured some thousands of women and children and, in order to gain a practical experimental understanding of sex differences, some hundreds of men. The difficult and necessarily slow process of analysis of these data is by no means complete and it must, of course, be some years before sufficient remeasurements of the same children at different periods of their growth can be taken to ensure definite certainty of results. A few salient points have, however, emerged.

\section{As ReGARDS ChILDREN.}

First measurements have been taken on two to three thousand children, but up to the present remeasurements have only been analysed in 419 cases, $187 \sigma^{*}$ and $232 q$ remeasured at intervals of from one to two years. The work is still going on, and I hope in time to secure much more complete series. Schools were visited in Cardigan, Merioneth, South Wales, Crewe, Malvern and Liverpool, and a side result of the observations has been to throw much light on movements of the population. The most important fact that emerges is the difference in rate of 
development between boys and girls. I put this point first because it should prove of great service to education and physical training if careful studies of growth could be made use of in the grouping and grading of boys and girls for educational purposes. A similar conclusion, arrived at by Dr. Morgan Rotch, Professor of Pediatrics at Harvard University, may be quoted here: "Somewhat different rules should be " adopted for the grading of girls than for that of boys. In fact, there is such a " manifest difference in chronologic, physiologic and anatomic ages of young " human beings in the formative stages of life according to sex that we should " endeavour to make practical use of this knowledge in our efforts to safeguard " their lives."

A second important result of remeasurement is that it brings out a tendency to a greater increase in head breadth than in head length, i.e., to an increase of cephalic index with growth. This applies to the majority of cases measured, though not to all. In early stages of growth this tendency is much more marked in girls than in boys. As this aspect of the work is only in its initial stages, the figures and percentages which follow must not be taken as altogether decisive, though interesting confirmation of some apparent results as to differences due to age and sex has appeared in recent anatomical studies of other aspects of growth and in educational reports on results of intelligence tests.

Of the 419 children remeasured after one year it was found that 75 per cent. had increased C.I. ; 5 per cent. had same C.I.; 20 per cent. had decreased C.I. :-

Changes of Cephalic Index on measurement after one year:-

\begin{tabular}{|c|c|c|c|c|c|c|c|c|c|c|c|}
\hline \multicolumn{6}{|c|}{ Decrease. } & \multicolumn{6}{|c|}{ Increase. } \\
\hline & & $3-4$. & $2-3$. & $1-2$. & $\begin{array}{c}\text { Less } \\
\text { than } 1 .\end{array}$ & $\begin{array}{c}\text { Less } \\
\text { than } 1 .\end{array}$ & $1-2$ & $2-3$. & $3-4$. & $4-5$. & $\begin{array}{l}\text { More } \\
\text { than 5. }\end{array}$ \\
\hline Girls & - & 1 & - & 9 & 37 & 90 & 60 & 18 & 4 & - & 1 over 7 \\
\hline Boys & - & - & 1 & 10 & 24 & 90 & 44 & 6 & 2 & 1 & \\
\hline
\end{tabular}

Increase varied 1-14 mm. in L. and B. Usual increase, L. 3-4, B 4-6. Greatest changes in C.I. $71 \cdot 4$ to $81 \cdot 3$ in $1 \frac{1}{2}$ years (male); $72 \cdot 7-83 \cdot 3$ in $1 \frac{1}{2}$ years (female).

The above figures are reckoned on a one year interval and show that of the 419 children, 316 or just over 75 per cent. had increased in cephalic index, 21 (10 $\delta$ and $11 \%$ ) had remained the same, and 82 had decreased (i.e., had increased more in H.I. than in H.B.). It is noticeable $(a)$ that all the really marked changes were in the direction of increased cephalic index; $(b)$ that, of the children showing an increase of one unit or more, 83 were girls as against 54 boys.

Actual increase in millimetres in head length and head breadth varies from 1 to 14, the most general increase being 3 to $4 \mathrm{~mm}$. in H.L., as against 4 to $6 \mathrm{~mm}$. in H.B. After the age of 7 in girls and 10 in boys there is a marked rise in actual number of millimetres increased. This age difference corresponds with Dr. Pryor's observations on the development of the bones of the hand by means of $\mathrm{X}$-rays. These show that a girl of $8 \frac{1}{2}$ has reached the same stage of ossification as a boy of 10 or more. He says: "The bones of the female ossify in advance of the male. This " is measured at first by days, then months, then years. . . . This may be " illustrated with the hands of twins of the same sex, in which there is a develop" ment of the same degree, while in twins of different sex the hand of the female " is much in advance of that of the male." Other observations of Dr. Pryor as 
to the union of the epiphysis of the lower extremity of the ulna with the shaft in girls at 16 or 17 and in boys at 17 to 20 parallel my observations on changes in colour, shape and head form, which are very slight or altogether absent after the age of 16 in girls, but continue markedly in boys.

Other points noted are that up to the age of eight years the girls showed rapid increase in cephalic index and marked changes in colour, while from 9 years onwards the changes were much slower and less marked. The boys up to the age of 10 showed only slight alterations in colour or in increase of cephalic index, but from 10 years onwards changes were rapid and marked.

Totals of all children measured show that cases of extreme dolichocephaly occur among boys only; no girls that I have measured had an index of less than 71 at any age, whereas an index of 66 is recorded among the boys.

The observations on colour show the same developmental sex differences. In making notes on eye-colour it has proved helpful to record the appearance in a gray or blue eye of a ring of brown round the pupil, flecks of brown rays out from the ring, and a general net of brown rings and rays over the gray. By this means it has been possible to record gradual darkening of the eye. The general tendency is, of course, for eye and hair to darken, but in girls the darkening is rapid until the age of 10, whereas in boys it is only slightly marked until that age. After that age the darkening continues slowly in both cases. In many cases the eye is dark from the first, and it is only the hair which darkens, the combination of dark eyes and light hair being as common up to the age of 10 as it is rare in adult life. In a few cases of both boys and girls the change in colour took the form of the appearance of a red tint. In a few others the intense pigmentation of very dark children seemed to modify slightly. In some very fair children the process of alteration of eye-colour went on, but the colouring that appeared was whitish yellow, so that the eye was still light, though there had been a change in it.

Another aspect of development which is being traced is the change in the shape of the forehead. Boys and girls seem more widely different in this than in any other feature discussed. The continuous frontal boss of infancy seems to disappear in girls a year or two earlier than in boys. In the latter it seems to resolve itself often into two bosses, which mark the nuclei of growth in the frontal bone and which interrupt the general tendency of the forehead to recede.

Interesting confirmation of a psychologic difference accompanying these physical differences in development comes from various education experts to whom the graphs of results have been shown.

\section{As REgARdS THE WoMEN.}

Measurements of 927 cases of women compared with 1,852 cases of men reported on by Dr. Fleure bear out Prof. Parson's and his conclusion that there is in the samples of population we have studied a greater tendency in women to pigmentation and to brachycephaly. A large proportion of women fall in the class-eye dark, hair dark; though, when it is a question of great intensity of pigmentation, i.e., black hair and very dark brown eye, the men's percentage is higher than that of the women.

At every stage of cephalic index up to 79 the men are in the majority, but at 80 and every stage above it the women are in the majority.

\section{Contrasts between Men and Women in Cephalic Index.}

$\begin{array}{lccccccc}\text { Index - } & 75 & 76 & 77 & 78 & 79 & 80 & 81 \\ \text { Men per cent. 11.17 } & 12 \cdot 31 & 13 \cdot 23 & 12 \cdot 69 & 13 \cdot 18 & - & - \\ \text { Women ", } & - & - & 11 \cdot 32 & 10 \cdot 79 & 11 \cdot 76 & 12 \cdot 51 & 10 \cdot 47\end{array}$

At no other Cephalic Index does the percentage rise above 10 per cent. of sample. 
That is, the majority of men fall into a group having cephalic index 75-79 inclusive and the majority of women into a group having cephalic index 77-81 inclusive. Of extreme cases 7.33 per cent. $q$ have C.I. 84 or over, as against 1.94 per cent. $\delta$, and 13.28 per cent. $\delta$ have C.I. less than 75 , as against $7 \cdot 66$. $q$ There seems every reason to suppose that a tendency to roundness of head in women and to a more oval shape in men is a sex character. The difference cannot be altogether accounted for by the extra strength of glabella and browridges in many men, for this is counteracted by the fact that many women have a greater projection of occiput. Again, measurements of very young children show that, before bony development of the forehead has set in, girls are rounder-headed than boys.

This conclusion seems to hold good for other groups than our own. E. Pittard in his "Crania Helvetica " gives the tables of measurements of series of homogeneous skulls from the Valais. These belong to a much broader-headed type than our own, for 56.9 per cent. of the female Valais skulls have indices ranging from 82 to 86 inclusive, while 57.8 per cent. of ours have indices ranging from 77 to 81 inclusive and only 18 per cent. of ours have indices 82-86. By comparing a series of $386 \delta$ and $288 q$ the following results were obtained from Pittard's measurements :-

(a) No women were 76 or less in C.I., as against 7 men.

(b) Only $\cdot 3$ per cent. of the women were 77 or less, as against $2 \cdot 8$ per cent. men.

(c) The greatest number of both men and women have an index of 85 . But in men that number represents only $11 \cdot 1$ per cent. of the whole, whereas in women it represents $14 \cdot 2$ per cent.

(d) The most brachycephalic skull is that of a woman C.I. 97, and the most dolichocephalic skulls are those of men ranging from C.I. 71-76 inclusive.

Pittard's tables also confirm our conclusions that women are slightly more prognathous than men, that the occipital prominence in women is lower and more projecting than in men, and that the relative size of the female frontal bone is greater.

Dr. Frets, in "Heredity of Head-Form in Man," states that women are more brachycephalic than men; and Fürst and Hansen, in a study of "Crania Grœnlandica," give 70.67 C.I. as average for men of that region, against 72 for women.

It is, therefore, clear that different limiting values must be used in deciding on race-type in men and in women. Some standard femaie types seem already to be indicated from the data in hand, though there is need for a great deal more work before they can be fully formulated.

The following is a preliminary study :-

Group A.-A type having most of the following characters :-C.I., 77-81; H.L., 181-193; H.B., 143-154; Ht., 5 feet 3 inches-5 feet 4 inches. Eye dark. Hair dark. Slight prognathism. Smooth or full forehead. Rather flat calvarium. Auricular height not great. Bizygomatic, 125-135.

[For purposes of comparison note that the group of dark men C.I. 75-79 have H.L. 194-204, H.B. 148-158, Bizygomatic 132-143. Less than 50 per cent. were prognathous. Forehead often receding. Height some inches greater than in women. This is from Dr. Fleure's measurements.]

Of 600 cases of dark-eyed, dark-haired women, $57 \cdot 8$ per cent. fell into this group. 
Actual figures :-

Number of Women.

Cephalic Index.

72
56
70
79
70

77

78

79

80

81

Of these 347 women, 219 were of Welsh extraction on both sides for many generations, in 35 cases the Welsh element in the ancestry predominated, though there were other factors. The remainder were women from various parts of the British Isles. In only three cases did the H.L. rise to $200 \mathrm{~mm}$. or more, 74 per cent. of the group had H.L. varying from 181 to 193 inclusive, 12 cases were 175 or less and one fell below 170. The maximum H.B. recorded was $161 \mathrm{~mm}$., but no other case reached 160 and 80 per cent. of the group varied from 143 to $154 \mathrm{~mm}$. inclusive. The minimum breadth recorded was $135 \mathrm{~mm}$. Only six of the 347 were exceptions as to calvarium - these had the boat-shaped vault, with auricular height nearly equal to head breadth, reminiscent of certain rather primitive skulls. Seventy per cent. had forehead full or smooth; $61 \cdot 3$ per cent were slightly prognathous. The main variation in height was 5 feet -5 feet 5 inches, though the majority were 5 feet 3 inches- 5 feet 4 inches. No case was more than 5 feet 9 inches, about 9 per cent. were slightly more than 5 feet 5 inches and about 9 per cent. were less than 5 feet.

The group was not so homogeneous as the fair-haired, light-eyed group of C.I. 77-81. It fell into two rather distinct groups as regards general build. One had a decidedly square build, the hands and ankles broad, fingers not tapering, often stubby, often the lunulæ were absent from the nails. In this variant of the type the zygomatic width was great, the complexion fresh or florid, the forehead low, the temporal ridges marked, the hair often growing low on forehead and temples in a V-shape. The other variant has the build slight, the zygomas small, no marked temporal ridging, the fingers tapering, with long nails and well-marked lunulæ and the ankles slender. The skin is often pale olive in tint, with no touch of colour in the cheeks.

Group B.-A type having most of the following characters :-C.I., 76 or less; H.L., 187-199; H.B., 137-148; height, much more varied than in A.; eye, dark; hair, dark; prognathism marked in degree; forehead often receding; calvarium rather high; bony development more marked than in A.

The type, though very distinct, never includes any very large percentage of any sample taken. The ancestry is mainly upland Welsh, but a few cases came from the North Yorks moorland, the rural parts of the Hereford and Malvern district, the County of Aberdeen and the West of Ireland. 88-8 per cent. had H.L. 182-199 as against 74 per cent. of type A., with H.L. 181-193. The maximum H.L. was $208 \mathrm{~mm}$. and the minimum 175. 79.7 per cent. have H.B. 137 to 148 as against 70 per cent. of A. with H.B. 143 to 150 . The maximum H.B. was 155 and the minimum 133. In this group the H.L. is a much more variable quantity than the H.B. Both eye and hair are much darker than in A., the percentage figures being: hair very dark, $72 \cdot 7$ in $\mathrm{B}$, and 63.6 in $\mathrm{A}$.; eye very dark, 63.6 in $\mathrm{B}$. and 53.6 in $\mathrm{A}$.; 73.8 per cent. were prognathous as against 61.3 per cent. of $A$. The forehead is less uniformly smooth or rounded, 40 per cent. having receding foreheads against 20 per cent. in A. An interesting point is that most cards in this group bear a record of some curious and often primitive characteristic, such as edge-to-edge bite, horseshoe-shaped palate, broad flattened nostril, deep set eyes, temporal hollows 
steep rise of vault to bregma. In some cases the hair grew very low on the temples and in one case the whole body skin was covered with really long, soft, fine hair, lighter in colour and softer and finer in texture than head or axillary hair. A few very dark women said that they were even darker in childhood and this possibility has been borne out by my observations on change of colour in little girls of this curiously interesting type.

Group C.-A type having most of the following characters:-C.I., 77-81; H.L., 180-192 ; H.B., 145-153; ht., 5 feet 4 inches to 5 feet 8 inches; eye, light; hair, dark flaxen to light brown; prognathism not so common as in A. or B., but the upper teeth often project outwards in a slanting direction. The forehead usually receding; calvarium, finely arched in profile; skin, fair; bizygomatic width, 120-125. The face is usually long, the lower jaw obtuse and the chin long and prominent. The build and general physical characters are more homogeneous in this group than in A. or B. The height is greater, two-thirds of the group being 5 feet 5 inches or over. The bones are strong, joints and ridges well marked. The hands and fingers are long, and the ankles slender. The actual measurements are larger than in other groups and there is much less variation. The skin is fair and fresh-coloured, though seldom florid as in the dark type. There is often a fine soft short down on the skin, the pores are not so large, and the texture of the skin is fine. It is often noticeably harsh and dry to the touch, especially in contrast to the soft freshness of some of the dark types. The ancestry is markedly different, only $31 \cdot 4$ per cent. being of Welsh extraction.

In almost every group measured there has been noted a type which seems of pathological, rather than racial, significance. The measurements are all very much below normal, the eye and hair are very pale and colourless, the build slight, the head narrow, often only $132-137 \mathrm{~mm}$. in breadth, and the general appearance listless. It is hoped that studies of the geographical occurrence of this type may help in discovering the causation of the condition.

Two other well-marked groups are being studied, the broad-headed dark and the broad-headed fair types. They are only a small percentage of the samples of population measured so far and further data are being collected before their general physical characters are discussed.

Three classes of women have been entirely omitted from the above groups :-

(1) Women having very light hair and dark eyes. This seems to be a condition of undeveloped pigmentation and therefore has little general racial significance.

(2) Those having a dark grey eye, but no brown pigment in it and very dark hair. It seems that these might justifiably be classed with the dark groups.

(3) Women with red hair. My cards are filed according to cephalic index for convenience and in every file there is a small group of red-haired women. Their general characters are, however, so heterogeneous that it seems difficult to classify them. Some have blue eyes and fair skin, some very dark brown eyes and fair skin, some are tall, some short and in every other way they differ so curiously that no distinctive group has yet emerged.

In collecting the above data, enquiries have been made as to occupations and preferences and these have been recorded on the cards and checked by other methods. The results seem to show some amount of correlation of psychical characters with physical make up. It is hoped that later these data may help by making it possible to suggest to boys and girls who are undecided about their future careers lines of thought which will prevent wasting of many years by trial of the wrong scheme of life. 
In conclusion, my grateful thanks are due to Professor Fleure for much help in initiating and carrying out the survey and for giving me the free use of all his own measurements of men and women.

R. M. FLEMING.

\section{Europe: Archæology.}

Brooks and Marr.

The Ice-Age and Man: A Note on Man, 1922, 5. By C. E. P. Brooks, 47
ith a Note by Prof. J. E. Marr, F.R.S.

I have studied Mr. Peake's classification of the Quaternary deposits with great interest, though I am unable to agree with him in all respects. There are two critical questions which must be solved before details can be worked outthe age of the Chalky Boulder Clay, and the position of the Chellean Industry.

Mr. Peake places the Chalky Boulder Clay in the Würmian and later than the Acheulian of Hoxne. The British Association Report on this subject is, however, quite definite* The Acheulian gravels lie above the Chalky Boulder Clay and separated from them by lignite and clay with temperate plants. The Chalky Boulder Clay must also be older than the 100-foot terrace of the Thames Valley. But the fauna of the latter, especially Corbicula fluminalis and Paludina diluviana, is characteristic of the first (Mindel-Riss) interglacial of the whole of northern Europe. We therefore have Chalky Boulder Clay-Mindelian. Similar conclusions were reached by $\mathrm{F}$. Leverett $\uparrow$ from a study of the weathering and erosion of the European deposits.

I am not an archæologist, but Penck's argument with regard to the position of the Chellean seems to me very clear, that as at Taubach and in the Grimaldi Grotto the Mousterian industry is contemporaneous with a temperate fauna, it must be in part interglacial. That being so, the Acheulean must correspond to the Rissian glaciation, and the Chellean must be Mindel-Riss. This statement is not inconsistent with the Mousterian occupying the whole of the Würm proper also. The close association of Chellean man with Elephas antiquus and the only really warm fauna of the Glacial Period is also in favour of its earlier position, for in the Riss-Würm interglacial Northern Europe does not appear to have reached its present temperature.

The great majority of British geologists fail to find any evidence of more than an oscillation of the ice-edge between the period of the Cromer Drifts and the Chalky Boulder Clay. A recession of the Scandinavian ice was followed after a pause by an advance of the British ice, but both are considered to belong to one period of glaciation.

I am glad to see that Mr. Peake throws doubt on the validity of the GunzMindel interglacial. I should like to go further and divide the whole Ice Age into two glaciations only, the Gunz-Mindel and the Riss-Würm, both composed of several oscillations and re-advances. Recent work by Scandinavian geologists t suggests that over the greater part of Norway and Sweden the ice only completely melted away once during the whole glacial period, but then for a very long interval. After the Rissian readvance there is no return of a really temperate fauna until the close of the Ice Age. Examine, for instance, the fauna of the "interglacial " mammal beds of Rixdorf, near Berlin. In spite of the large number of bones examined, the warm element is represented solely by one tooth of Elephas antiquus and one tooth of Rhinoceros Merckii, both possibly derived.

* B.A. Report, 1896, pp. 400-415, or W. B. Wright, "The Quaternary Ice Age." London (Macmillan), 1914, p. 273.

† Leverett, F., “Comparison of North American and European Glacial Deposits," Zs. Gletscherk, Berlin, 4, 1910.

† Ahlmann, H. W : Son, “ Geomorphological Studies in Norway." Stockholm, Geogr. Ann., 1, 1919, pp. 1-187, 193-252. 